сновку, що використані в дослідженні опитувальники ТН діагностують різні аспекти психічної реальності.

Страхи соціального походження (не відповідати очікуванням навколишніх) взаємопов'язані 3 толерантністю до невизначеності; вони фрормують підвищені вимоги до себе, знижують рівень самоприйняття та сприяють формуванню співзалежної поведінки. Вираженість страхів будь-якої природи негативно впливає на психологічне благополуччя дорослої людини, зумовлює низку психологічних проблем і навіть патопсихологічних розладів.

Список використаних джерел

1. Захаров А. И. Дневные и ночные страхи у детей. - СанктПетербург: Речь, 2007. - 320 с

2. Корнилова Т. В. Новый опросник толерантности-интолерантности к неопределенности. Психологический журнал. 2010. - Том 31, № 1. - С. 74 86.

3. Луковицкая Е. Г. Социально-психологическое значение толерантности к неопределенности : дис. ... канд. психол. наук : 19.00.05. - Санкт-Петербург, 1998. - 173 с.

4. Мэй Р. Смысл тревоги. - Москва: Независимая фрирма "Класс", 2001. -384 c.

5. Осин Е. Н. Факторная структура русскоязычной версии шкалы общей толерантности к неопределенности Д. Маклейна. Психологическая диагностика. 2010. № 2. C. 65-86. URL: https://publications.hse.ru/articles/67229830

6. Ханин Ю. Л. Краткое руководство к применению шкалы реактивной и личностной тревожности Ч.Д. Спилбергера. - Ленинград: ЛНИИ ФК, 1976. - 18 c

Olga Potonska, PhD student

University of Modern Knowledge, Kyiv, Ukraine
7. Beck J. S. Complex cognitive therapy treatment for personality disorder patients. Bulletin of the Menninger Clinic. 1998. Vol. 62(2). P. 170-194.

8. McLain D. L. The MSTAT-I: A New Measure of an Individual's Tolerance for Ambiguity. Educational and Psychological Measurement. 1993. Vol. 53(1). P. 183-189. DOI: https://doi.org/10.1177/0013164493053001020

9. StatSoft, Inc. Электронный учебник по статистике. Москва, StatSoft. 2012. URL: http://www.statsoft.ru/home/textbook/default.htm.

References

1. Zaharov A. I. Dnevnyie i nochnyie strahi u detey. Sankt-Peterburg : Rech, 2007. $320 \mathrm{~s}$.

2. Kornilova T. V. Novyiy oprosnik tolerantnosti-intolerantnosti k neopredelennosti. Psihologicheskiy zhurnal. 2010. Tom 31, \# 1. S. 74-86.

3. Lukovitskaya E. G. Sotsialno-psihologicheskoe znachenie tolerantnosti k neopredelennosti : dis. ... kand. psihol. nauk : 19.00.05. Sankt-Peterburg, 1998. $173 \mathrm{~s}$.

4. Mey R. Smyisl trevogi. Moskva: Nezavisimaya firma "Klass", 2001. 384 s.

5. Osin E. N. Faktornaya struktura russkoyazyichnoy versii shkalyi obschey tolerantnosti k neopredelennosti D. Makleyna. Psihologicheskaya diagnostika. 2010. \# 2. S. 65-86. URL: https://publications.hse.ru/articles/67229830

6. Hanin Yu. L. Kratkoe rukovodstvo k primeneniyu shkalyi reaktivnoy i lichnostnoy trevozhnosti Ch.D. Spilbergera. Leningrad: LNII FK, 1976. 18 s.

7. Beck J. S. Complex cognitive therapy treatment for personality disorder patients. Bulletin of the Menninger Clinic. 1998. Vol. 62(2). P. 170-194.

8. McLain D. L. The MSTAT-I: A New Measure of an Individual's Tolerance for Ambiguity. Educational and Psychological Measurement. 1993. Vol. 53(1). P. 183-189. DOI: https://doi.org/10.1177/0013164493053001020

9. StatSoft, Inc. Elektronnyiy uchebnik po statistike. Moskva, StatSoft. 2012. URL: http://www.statsoft.ru/home/textbook/default.htm.

Надійшла до редколегії 30.09.20

Рекомендована до друку 28.10.20

\title{
THE IMPACT OF CHILDREN'S FEARS ON ADULT TOLERANCE
}

Objective: To confirm the impact of childhood fears on adult tolerance. Methods: questionnaire of the author on the childhood fears; MSTAT-I Tolerance Scale for Ambiguity of Several Types of Incentives; New questionnaire of tolerance for NTN uncertainty. Identified: classification and quantitative parameters of childhood fears; fears of social origin associated with tolerance of uncertainty. It is important to adapt quickly and make non-standard decisions to be successful in today's changing world. One of the main obstacles is the existence of stereotypes - a rigidly stable image of a person's consciousness in terms of objectively existing phenomena makes it possible to perceive the surrounding reality in a convenient form. Childhood fears are their basis. Despite this, a need for comprehensive research exists. The importance of the construct of tolerance for uncertainty (from now on referred to as TN) - the ability of a person to accept unknown information, resist the contradictions of information, and overcome conflict and tension arising in a duality situation is extremely increasing in modern psychodiagnostics. The uncertainty tolerant person is described as one who accepts the novelty and uncertainty of situations and can act productively in them. In contrast, the intolerant person is described as one who does not accept the novelty of situations, the world's diversity and is stressed when the possibility of multiple interpretations of stimuli. We view the tolerance of uncertainty as to the opposite of the stereotypical behavior from the psychological perspective. The scope of this publication is to show and substantiate the impact of childhood fears on adult tolerance. Further the development of this issue is important both in the theoretical context - for understanding the dynamism of the mind in the modern changing world, where uncertainty is a common condition for life, and in practical terms - for solving important problems of forming human tolerance social interaction.

Keywords: intolerance, stereotypization, fear, tolerant of imponderability.

Bulletin of Taras Shevchenko National University of Kyiv. Series "Psychology". № 1(11), pp. 57-63 (2020) УДК 159.923

DOI: https://doi.org/10.17721/BSP.2020.1(11).11

\section{ISSN 1728-3817}

(C) Taras Shevchenko National University of Kyiv,

Publishing and Polygraphic Center "Kyiv University", 2020

Лариса Терлецька, канд. психол. наук, доц. Ірина Кухар, магістр

Київський національний університет імені Тараса Шевченка, Київ Україна

\section{ВЗАЄМОЗВ'ЯЗОК СТРАХІВ, ФОБІЙ, ТРИВОЖНОСТІ IЗ САМОСТАВЛЕННЯМ ОСОБИСТОСТІ}

У статmі представлено результати емпіричного дослідження взаємозв'язку страхів, фобій, тривожності із самоставленням особистості юнацького віку (ранього і пізднього). Проаналізовані поняття: самосвідомість, самоставлення, страхи, фобії, тривожність, юнацький вік. Використані діагностичні методики дослідження (опитувальник самоставлення Століна-Пантелєєва, С-тест В. Леві, опитувальник тривожності Спілбергера-Ханіна); методи математичної статистики (коефіцієнт кореляції r-Спірмена).

Ключові слова: страхи, фобії, тривожність, емоції, самоставлення, особистість.

Вступ. Однією з найважливіших детермінант внутрішньої активності особистості $€-$ самоставлення. Новизна нашого дослідження полягає в уточненні та систематизації тематичних проблем вивчення самоставлення, механізмів його формування в межах різних теоретичних концепцій і підходів, що надало підстави розробити модель детермінації самоставлення особистісними та ситуа- ційними факторами, виявити особливості структури самоставлення, дослідити взаємозв'язки між страхами, фобіями, тривожністю та компонентами самоставлення особистості юнацького віку.

Мета статті. Розглянути характеристики впливу усвідомлення страхів, фобій, тривожності на самоставлення особистості; виявити особливості прояву зв'язку 
страхів та фобій із самоставленням особистості раннього та пізднього юнацького віку.

Методи. Згідно з метою було проведено емпіричне дослідження, в якому респондентами стали представники шкільної та студентської молоді. Адже саме в юнацькому віці відбувається активний розвиток та становлення всіх компонентів самосвідомості, у тому числі, і самоставлення. Використовувались такі методи: теоретичні - аналіз, систематизація й узагальнення психологічних даних з проблеми дослідження; емпіричні психодіагностичні методики: тест-опитувальник самоставлення (В. Столін, С. Пантелєєв); тест "Чего мы боимся" В. Леві (С-тест); "Опитувальник ієрархічної структури актуальних страхів особистості" (Ю. Щербатих і О. Івлєва, ICAC); тест на особистісну та ситуативну тривожність Спілбергера-Ханіна. Також були використані методи математично-статистичної обробки даних, зокрема критерій Манна-Уітні та коефріцієнт кореляції r-Спірмена.

Огляд літератури. Самосвідомість $є$ вищим рівнем розвитку свідомості людини, основою формування її розумової активності і самостійності особистості в ії судженнях, відносинах, діях і вчинках. А самоставлення $€$ емоційним компонентом самосвідомості, який складається із сукупності емоційних переживань і оцінних суджень особистості, пов'язаних 3 розумінням особистістю свого "Я" як суб'єкта, що відрізняється від інших. У психологічній науці існують суперечливі погляди щодо психологічної природи самоставлення особистості. Одні вчені, пов'язують самоставлення 3 мотиваційною сфрерою особистості. Такої позиції притримуються В. Вілюнас, С. Крягжде, В. М'ясищев, В. Ядов та С. Якобсон. Інші ж вчені (Л. Божович, Ю. Приходько, Г. Щукіна, В. Мухіна) пов'язують самоставлення з емоційною сферою. В. М'ясищев та В. Ядов вважають джерелом дії цього феномену - активність.

До того ж, на сьогодні визначають наявність трьох самостійних підходів щодо вивчення сутності самоставлення як психічного феномену, а семе: 1) як афективний компонент самосвідомості особистості; 2) як риса особистості; 3) як компонент саморегуляції. Однак, як зазначає С. Пантелєєв, можна визначити більш-менш прийнятну для більшості науковців позицію, згідно 3 якою самоставлення $є$ цілісним, одновимірним та універсальним утворенням, що виражає міру позитивного ставлення індивіда до образу власного "Я"; і є інтеграцією окремих самооцінок.

Методологія. Самоставлення включає багато структурних компонентів, такі як: самоповага, аутосимпатія, очікування позитивного ставлення від інших, самоінтерес, самовпевненість, ставлення інших, самоприйняття, самокерування, самопослідовність, самозвинувачення, самоцікавість, саморозуміння. Крім того, воно тісно пов'язане з самооцінкою - оцінка людиною своїх якостей, себе, рівня успішності власної діяльності, оцінки своєї особи іншими людьми, виходячи з системи цінностей людини. Самооцінка - суб'єктивне утворення в людській психіці, але воно є відображенням норм і оцінок, що існують у суспільстві та в міжособистісних відносинах. Характер їх взаємозв'язку сприймається дослідниками по-різному: самооцінка - структурний компонент самоставлення; самоставлення включається у структуру самооцінки; самоставлення прирівнюється до самооцінки або ототожнюється з нею; самоставлення - похідне від сукупності окремих само оцінок. Таким чином, самоставлення як полімодальна емоційно-ціннісна система займає особливе місце в системі ставлень особистості. Воно є однією зі складників суб'єктного ядра особистості та структури її самосвідомості, виражає особливості ставлення людини до самої себе і забезпечує центру- вання іï̈ внутрішнього простору й формування смислового вектора життєвого шляху.

Оскільки самоставлення особистості напряму пов'язане з впевненістю у собі, то можна припустити, що вона також корелює із наявністю страхів і фобій. Взагалі, страх - це психічний стан, що виникає на основі інстинкту самозбереження як реакція на дійсну або уявну небезпеку у вигляді обтяжливого емоційного стану. 3 погляду психології вважається негативно забарвленим емоційним процесом. Страх має багато причин як суб'єктивного (мотивація, емоційно-вольова стійкість), так і об'єктивного порядку (особливості ситуації, складність завдань, перешкоди). Страх має свої різноманітні форми. У дослідженні показано схему вираження форм страху залежно від його інтенсивності: тривога - переляк - боязнь - страх - жах - паніка. Ці форми (рівні) являють собою поступове ускладнення оцінки людиною страхогенної ситуації (ситуації, які можуть нести загрозу біологічному, духовному, соціальному буттю індивіда).

Д. Карнегі класифікує страх як: ситуативно та особистісно обумовлений; гострий та хронічний; інстинктивний та соціально опосередкований; реальний (за наявності конкретної загрози) та уявний (на рівні уявлень). Хвилювання та тривожність визначають як стани, що відповідають страху та почуттю тривоги. За ступенем прояву він поділяє страх на жах, переляк, власне страх, тривогу, побоювання, занепокоєння та хвилювання [5].

$€$ різноманітні схеми вираження форм та інтенсивності страху. Ці фрорми являють собою поступове ускладнення оцінки людиною страхогенної ситуації. Використовуючи праці дослідників страху В. Андрусенка, В. Дерябіна, М. Савіної та інших М. Мовчан створює узагальнюючу схему прояву страху згідно з посиленням психологічної напруги, пов'язаної з реакцією на несприятливі життєві обставини, а саме: тривога - переляк боязнь - страх - жах - паніка [3].

Стан, у якому перебуває суб'єкт, якщо джерело небезпеки невизначене або неусвідомлене, називається тривогою. Страх і тривога як відносно епізодичні реакції мають свої аналоги в формі більш складних психічних станів: страх - у вигляді боязливості, а тривога - у вигляді тривожності. якщо страх, і частково тривога, швидше ситуаційно, ніж особистісно обумовлені психічні феномени, то боязливість і тривожність, навпаки, скоріше особистісно мотивовані і, відповідно, більш стійкі.

Тривога $є$ таким емоційним станом, який має безпредметний характер. "Дане почуття відображає об'єктивний стан індивіда, що перебуває в певних взаємовідношеннях 3 оточуючим світом". Причиною страху є зовнішнє, конкретне джерело небезпеки, а для того щоб з'явилася тривога таке джерело не потрібне. Для тривоги потрібне щось невідоме, яке може з'явитися в результаті уяви, думки тощо. Тобто тривога властива лише людині. "Страх - реакція на фактично існуючі несприятливі обставини, а почуття тривоги - це занепокоєння, що викликане припущенням про можливий несприятливий результат" [4].

I страх, і тривога мають спільний емоційний компонент у вигляді почуття хвилювання чи занепокоєння. У цих двох поняттях відображенні сприйняття погрози або відсутність почуття безпеки. Ж. Годфруа стверджує, що 3 погляду фрізіології, тривога не відрізняється від страху. Основна відмінність у тому, що тривога викликає активізацію організму до того, як відбувається очікувана подія. Тривога являє собою перехідний стан, вона слабшає, як тільки людина дійсно стикається з очікуваною ситуацією [3]. Для виникнення страху необхідно, щоб було якесь зовнішнє джерело небезпеки, якась помітна загроза. Для того, щоб виникла тривога, жодних видимих ворогів не 
потрібно, достатньо лише подумати, уявити і тривога може з'явитися. Страх - це реакція на фрактично наявні несприятливі обставини, а почуття тривоги - це занепокоєння, що викликане припущенням про можливий несприятливий результат. Тривога з'являється тоді, коли загроза для індивіда має невизначений, абстрактний характер, а мозок за такої умови не зміг ще чітко вибрати оптимальну стратегію поведінки [4].

Крайнім проявом страху $є$ фобія. Щоб реакцію можна було класифікувати як фобія страх повинен бути нав'язливим, ірраціональним, стійким та інтенсивним. Це страх, який пов'язаний з певною ситуацією чи групою уявлень і який не виникає за їх відсутності. Фобія є психологічним розладом, у той час як страх - звичайна здорова емоція.

Таким чином, можна висунути гіпотезу, що страх провокує тривожність, яка супроводжується невпевненістю, унаслідок чого формується неадекватна самооцінка на самоставлення.

Особистості, що відносяться до категорії високотривожних, схильні сприймати загрозу своїй самооцінці і життєдіяльності у великому діапазоні ситуацій і реагувати дуже вираженим станом тривожності. Якщо психологічний тест показує у досліддуваного високий показник особистісної тривожності, то це дає підставу припускати у нього появу стану тривожності в різноманітних ситуаціях, особливо коли вони стосуються оцінки його компетенції та престижу.

Для низькотривожних людей, навпаки, потрібно пробудження активності, підкреслення мотиваційних компонентів діяльності, збудження зацікавленості, висвічування почуття відповідальності у вирішенні тих чи інших завдань.

Стан реактивної (ситуативної) тривоги виникає внаслідок попадання у стресову ситуацію і характеризується суб'єктивним дискомфортом, напруженістю, занепокоєнням і вегетативним збудженням. Природно, це стан відрізняється нестійкістю в часі і різною інтенсивністю залежно від сили впливу стресової ситуації. Таким чином, значення підсумкового показника за даними підшкалами дозволяє оцінити не тільки рівень актуальної тривоги випробуваного, а й визначити, чи перебуває він під впливом стресової ситуації і яка інтенсивність цього впливу на нього. Саме тому в подальшому аналізі результатів дослідження до уваги буде братись тільки особистісна тривожність, яка розглядається як стійка характеристика людини.

Особистісна тривожність являє собою конституційну межу, яка обумовлює схильність сприймати загрозу в широкому діапазоні ситуацій. У разі високої особистісної тривожності кожна 3 цих ситуацій буде володіти стресовим впливом на суб'єкта і викликати у нього виражену тривогу. Дуже висока особистісна тривожність прямо корелює з наявністю невротичного конфллікту, з емоційними і невротичними зривами і психосоматичними захворюваннями.

У цьому дослідженні тривожність розглядається як 3 погляду її зв'язку зі страхом, так і з самоставленням особистості. На сьогоднішній день існує чимало досліджень та наукових праць, які обговорюють подібності та відмінності між тривогою і страхом. На перший погляд, як указує В. Астапов, різниця проста: страх - це реакція на конкретно існуючу загрозу; тривожність - це стан неприємного передчуття без видимої причини. У деяких дослідженнях страх розглядається як фундаментальна емоція, а тривожність, яка фрормується на його основі, часто у комбінації з іншими базовими емоціями, як більш складне емоційне явище. Натомість П. Тілліх вважає, що страх і тривожність $€$ нерозривними: вони тісно пов'язані між собою. Він визначає тривожність як страх перед невідомим. Таким чином, тривога - це базисна реакція, загальне поняття, а страх - це вираз тієї ж якості, але в об'єктивній формі. Саме тому тривога надалі розглядатиметься у тісному зв'язку зі страхом [8].

3. Фрейд виокремив три основних види тривожності: об'єктивну, викликану реальною зовнішньою небезпекою; невротичну, викликану небезпекою невідомою і невизначеною; моральну, названу ним "тривожність совісті". Об'єктивна тривога $\epsilon$ емоційною відповіддю на загрозу зовнішнього світу, $є$ синонімом страху і може послаблювати здатність людини ефективно боротися з джерелом загрози. За його висновками, до складу тривожності входять поняття: "тривога", "страх", "занепокоєння". Страх $€$ афективним відображенням у свідомості людини конкретної загрози для її життя і благополуччя. Тривога трактується як емоційно загострене відчуття майбутньої загрози. Тривога (на відміну від страху) не завжди негативно сприймається, оскільки вона можлива й у вигляді радісного хвилювання, хвилюючого очікування.

Тривожність також має вагомий вплив на самоставлення людини. Інтенсивність тривоги здебільшого відбиває індивідуальні особливості особистості. На думку Р.Грановської, занижена самооцінка виявляється в постійній тривожності, страхові перед негативною думкою про себе, у загостреній чутливості до всього, що якось зачіпає особистість. Такі люди хворобливіше реагують на критику, сміх, осуд, болісно сприймають невдачі у навчанні. Причиною тривожності на психологічному рівні може бути неадекватне сприйняття суб'єктом самого себе. Тривожність обумовлена конфрліктною побудовою самооцінки, коли одночасно актуалізуються дві протилежні тенденції - потреба оцінити себе високо, з однієї сторони, і почуття невпевненості - з іншої. Особистості, що відносяться до категорії високо тривожних, схильні сприймати загрозу своїй самооцінці та життєдіяльності у широкому діапазоні ситуацій та реагувати явно вираженим станом тривожності. Загалом, висока тривожність деформує уявлення про себе, своє теперішнє та майбутнє, заважає конструктивній взаємодії з оточенням. Виходячи зі всього вищесказаного, можна сказати, що самоставлення особистості, а саме юнаків, залежить від рівня тривожності. Високий рівень самоставлення у тривожних людей може виступати у ролі психологічного захисту. Бажання мати позитивний образ "Я" нерідко спонукає людину перебільшувати свої позитивні якості й зменшувати недоліки [2].

Таким чином, люди з високим рівнем особистісної тривожності характеризуються конфлліктним сприйняттям різних сторін Я-концепції, зокрема, чим вищим $є$ рівень особистісної тривожності, тим негативніше сприймається власна зовнішність та фрізична привабливість, а спілкування не дає повною мірою розкрити свій внутрішній світ. Тривожна особистість відчуває себе нещасливою та незадоволеною життям, невпевнена у собі. Самооцінка високотривожних людей часто занижена, а високий рівень самоставлення можна пояснити дією захисних механізмів психіки. До того ж, людей, схильних до фобій, постійно мучить неослабна тривога. Саме тому, вимірювання рівня тривожності $€$ необхідною процедурою в даному дослідженні.

Результати дослідженя. Для проведення емпіричного дослідження було обрано респондентами представників шкільної та студентської молоді, а саме 120 осіб: 60 учнів 10-11 класів ЗОШ №2 та №3 м. Вишгород (15-17 років) та 60 студентів 3 факультету психології Київського національного університету імені Тараса Шевченка 4 курсу (20-21рік). Така вибірка сформована 
на підставі того, що саме в цьому віці відбувається активний розвиток та становлення всіх компонентів самосвідомості, у тому числі і самоставлення. За віковою періодизацією М. Савчин і Л. Василенко вибірку поділено на дві групи: представники ранньої (15-18 років) та пізньої (18-23 роки) юності або старшого шкільного і студентського віку.

Відомо, що ранній юнацький вік є певною межею між дитинством та дорослістю, вузловим періодом формування особистості, найбільш сенситивним для розвитку самоставлення (С. Рубінштейн, Д. Фельдштейн). Тому в психологічній літературі суттєву увагу приділяють проблемі ефективного розвитку самоставлення юнаків цього віку, особливо тих, розвиток яких відбувається в соціально несприятливих умовах. У багатьох сучасних дослідженнях старший шкільний вік розглядається як важливий поворотний рубіж онтогенетичного розвитку, що пов'язаний з якісно новим етапом формування самосвідомості, самоставлення (Б. Ананьєв, К. Абульханова-Славська, Р. Бернс, Л. Божович, Д. Ельконін, О. Леонтьєв, С. Максименко, С. Рубінштейн, В. Столін, І. Самуйлова, І. Слободчиков, Г. Прихожан, І. Чеснокова, Д. Фельдштейн та ін.)

У ранній юності людина знову починає звертатися до власної особистості. У цей період вперше в ії розвитку акти самосвідомості - самопізнання, самоспостереження, самоставлення, саморегулювання поведінки і діяльності стають однією з необхідних потреб особистоті. Самоставлення і самопізнання, розвиваючись у процесі спілкування та самоспостереження, водночас формують і більш-менш стійку самооцінку. Юнак має регулювати свою поведінку в системі взаємовідносин 3 іншими не тільки з погляду самоставлення окремих своїх вчинків з вимогами оточуючих, але і з погляду відповідності своїх вимог до самого себе [9].

Якісні зміни самосвідомості у юнаків старшого шкільного віку можуть призвести до підвищення конфрліктності, протиріччя самоставлення, загострення особистісних переживань (Є. Андрєєва, Б. Братусь, Д. Демидов, Л. Запорожець, Е. Еріксон та ін.). Саме тому дослідники підкреслюють важливість психологічної підтримки юнаків. Крім того, за допомогою створення умов для формування позитивного самоставлення закладаються основи розвитку і становлення особистості як повноцінного активного суб'єкта діяльності і члена суспільства. На даний момент збільшується необхідність у дослідженні психологічних фракторів, що впливають на розвиток особистості юнаків, особливості їх самоставлення.

Студентський вік $€$ особливим періодом життя і розвитку особистості, який $є$ перехідним від дитинства до дорослості. Заслуга самої постановки проблеми студентства як особливої соціально-психологічної та вікової категорії належить психологічній школі Б. Ананьєва. Пізній юнацький вік характеризується найбільшими змінами, що визначаються високими показниками розвитку інтелектуальних функцій. У цьому періоді формуються усталені властивості особистості, засвоюються норми відносин між людьми, профресійно-трудові вміння і навички. У вітчизняній психології період пізнього юнацтва характеризується досягненням нового рівня розвитку внутрішньої позиції, самосвідомості і самоповаги, у цьому віці відбувається активне становлення особистості, побудова образу світу, прогнозування свого місця у цьому світі, планування свого майбутнього і способів самоздійснення.

Розвиток самосвідомості $€$ центральним психологічним процесом у пізньому юнацькому віці. Саме самосвідомість спонукає особистість узгоджувати всі свої прагнення і вчинки образом власного "Я". Усе це супроводжується різними видами діяльності, в які залучений юнак: навчальна, виробнича, творча. У цей період розвивається самоставлення як компонент самосвідомості, що дає змогу оцінювати власні здібності, якості, що дозволяє коригувати і вдосконалюватись як особистість. Самоставлення в пізньому юнацькому віці відбувається також завдяки пізнанню інших осіб, які $€$ в оточенні. Соціально-психологічна особливість цього вікового періоду характеризується набуттям досвіду у спілкуванні, становлення світогляду та соціальних установок. Діяльність у цьому віці наповнена мотивами засвоєння знань, спрямованими на професію; з'являються соціальні та особистісні зовнішні мотиви, передусім мотиви досягнення. Поряд з навчанням провідною діяльністю стає спілкування. Побудовані на основі певних морально-етичних вимог і соціальних норм взаємини роблять міжособистісне спілкування юнаків діяльністю, всередині якої формуються спільні погляди на життя, на майбутнє [9].

Як зазначає Ж. Сидоренко, успішність проходження кризи ідентичності, що виступає, згідно з концепцією Е. Еріксона, важливим життєвим завданням пізньої юності, залежить від розвитку рефлексивних здібностей особистості, від адекватного самоставлення молодої людини. Неадекватне, деструктивне самоставлення, що супроводжуються низьким рівнем самоповаги та самосприйняття, не тільки блокує процес особистісного зростання, але й стає підґрунтям делінквентної та ауто агресивної поведінки. У свою чергу, конструктивне ставлення до себе зумовлюватиме адекватність та результативність життєвих завдань людини, ефективність моделювання майбутнього. До того ж, продуктивним та своєчасним $є$ виявлення проблемних аспектів самоставлення осіб юнацького віку для подальшого вивчення можливостей їх ефективної корекції [6]

У цьому віці перебудовуються всі колишні ставлення до світу і самого себе, зароджуються значущі новоутворення, які детермінують розвиток значущих особистісних структур. Одним з центральних моментів тут є зміна підстав, критеріїв для самооцінки - вони зміщуються, кажучи словами Л. Виготського, "із зовні, у всередину", набуваючи якісно інші форми, порівняно з критеріями оцінки людиною інших людей. Перехід від приватних самооцінок до загальної, цілісної (зміна підстав) створює умови для формування в повному розумінні слова власного ставлення до себе, досить автономного від ставлення і оцінок оточуючих, приватних успіхів і невдач, різного роду ситуативних впливів [9].

О. Камінська розглядає розвиток самоставлення в юнацькому віці як компоненту самосвідомості у процесі інтегрування образу самого себе. Дослідниця дійшла висновку, що кожен акт самосвідомості - це взаємодія самопізнання і самоставлення, яке виникає та формується в процесі самопізнання на різних його рівнях і суттєво впливає на весь процес розвитку самосвідомості, визначаючи його специфіку, спрямованість й індивідуальність [1].

Найважливішою детермінантою розвитку самоприйняття представників періоду пізньої юності, що забезпечує прийняття ними себе як унікального соціальноособистісного феномена, вважається сім'я, а також внутрішньо університетська, внутрішньо групова взаємодія з викладачами й однолітками. Характеризуючи самоставлення юнаків, важливо також виділити такі його особливості: збільшення ступеня адекватності; усталеність структурних компонентів самоставлення; сформованість самоставлення в цілому та його чутливість до зовнішніх і внутрішніх впливів. Крім того, саме в пізній юності завершується формування емоційноціннісного ставлення до себе, тобто "оперативна само- 
оцінка" починає містити відповідність поведінки, власних поглядів і переконань, результатів діяльності. Самооцінка і самоставлення взаємопов'язані між собою, оскільки є складовими однієї системи. Вони зумовлюють адекватність чи неадекватність образу "Я", що пов'язується 3 розвитком когнітивного компоненту самосвідомості (здатності до самопізнання) та з мотивацією до пізнання власної особистості. Таким чином, самосвідомість в юнацькому віці набуває якісноспецифічний характер. Вона пов'язана з необхідністю оцінювати якості своєї особистості з урахуванням конкретних життєвих устремлінь, у зв'язку з рішенням завдання професійного самовизначення [9].

Процес становлення самоставлення в особистості не $є$ лише інтрапсихічним процесом - ставлення людини до себе виникає та розвивається в системі взаємозв'язків із оточуючим світом. А. Бандура зазначав, що концепції людей, їх поведінка та їхнє оточення взаємно детерміновані, індивіди не є безпорадними об'єктами, що контрольовані силами оточення, у той же час вони не $є$ абсолютно вільними істотами, які можуть робити все що завгодно. Видатний вчений О. Леонтьєв підкреслював визначальне значення для формування людської особистості через діяльність суспільного фактора: Сутність особистості полягає в сукупності всіх суспільних зв'язків, в яких ми реально існуємо, в яких і народжується особистість. Вчений вбачав юнацький вік одним з критичних, значущих періодів для становлення особистості людини [9].

Трикомпонентну схему ставлення до себе як суб'єкта учбової діяльності пропонує І. Кон. Він виокремлює такі складники: когнітивний - знання себе як учня, студента, уявлення про себе в різній віковій перспективі; афективний - оцінка й емоційні переживання власних учбових досягнень і невдач, міркувань, самоприйняття і самооцінки особистісно значущих властивостей; конативний - рефлексивний самоконтроль в учбовій діяльності. Оскільки загальновідомим $€$ визнання ролі спілкування як важливої діяльності у юнацькому віці, то можна з упевненістю вважати його найсприятливішим i гостро сенситивним для становлення і формування самоприйняття особистості. Тому заклад вищої освіти, навчально-виховний процес, де відбувається активна міжособистісна комунікація і перцепція, слід розглядати як одну з найважливіших детермінант їхнього самоприйняття і загального розвитку [9].

Для пошуку взаємозв'язку між самоставленням та страхами, фообіями та особистісною тривожністю було використано коефіцієнт кореляції r-Спірмена.

В отриманих результатах було виявлено велику кількість середніх $(0,3<r<0,6)$ та декілька сильних $(r>0,6)$ зв'язків між самоставленням та рівнем страху і показником особистісної тривожності.

Таблиця 1

Взаємозв'язки самоставлення та його компонентів з загальним рівнем страху та особистісною тривожністю на рівні вибірки представників раннього юнацького віку

\begin{tabular}{|l|c|c|}
\hline \multicolumn{1}{|c|}{ Показники самоставлення особистості } & Рівень страху & Показник особистісної тривожності \\
\hline Інтегральне самоставлення & $-0,572^{* *}$ & $-0,639^{\star *}$ \\
\hline Самоповага & $-0,562^{* *}$ & $-0,634^{* *}$ \\
\hline Аутосимпатія & $-0,399^{* *}$ & $-0,541^{* *}$ \\
\hline Очікуване відношення від інших & $-0,396^{* *}$ & $-0,402^{\star *}$ \\
\hline Самоінтерес & $-0,310^{*}$ & $-0,484^{* *}$ \\
\hline Самовпевненість & $-0,469^{* *}$ & $-0,343^{* *}$ \\
\hline Самоприйняття & $-0,397^{* *}$ & $-0,517^{* *}$ \\
\hline Самопослідовність & & $-0,384^{* *}$ \\
\hline Саморозуміння & $-0,481^{* *}$ & $-0,646^{\star *}$ \\
\hline
\end{tabular}

Примітка: ** $<<0,01$ - показник кореляції дуже значущий; * $p<0,05$ - показник кореляції значущий

Звідси можемо констатувати такі взаємозв'язки:

- Сильний обернений зв'язок $(r=-0,639, p=0,01)$ між інтегральним показником самоставлення та рівнем особистісної тривожності. Тобто, що вищим $€$ рівень тривожності у людини, то нижчим $є$ рівень самоставлення, і навпаки.

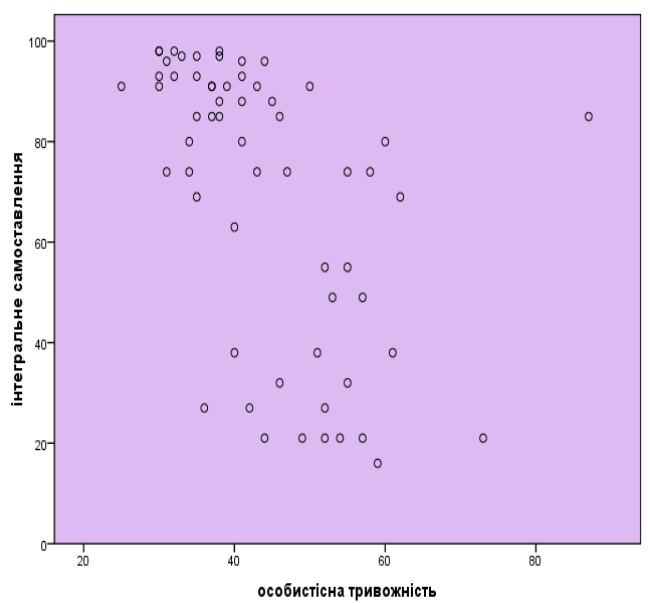

Рис. 1. Діаграма розсіювання,

що показує взаємозв'язок між рівнем особистісної тривожності та інтегральним показником самоставлення на рівні вибірки раннього юнацького віку
За діаграмою розсіювання за змінними "інтегральне самоставлення" та "особистісна тривожність" можна побачити, що зв'язок є лінійним, оберненим і сильним. На це вказує розташування точок, через які можна провести пряму. За цією діаграмою можна побачити викиди: вісь $X-37$, вісь $Y-27$; вісь $X-89$, вісь $Y-85$.

- Сильний обернений зв'язок ( $r=-0,634, p=0,01)$ між самоповагою та особистісною тривожністю. Тобто, що вищим $€$ рівень самоповаги, то меншим $є$ рівень тривожності, й навпаки.

- Обернений зв'язок середньої сили ( $r=-0,541$, $\mathrm{p}=0,01)$ між аутосимпатією та показником особистісної тривожності. Тобто, що меншим $є$ рівень аутосимпатії, то вищим $€$ рівень тривожності, та навпаки.

- Обернений зв'язок середньої сили ( $r=-0,402$, $\mathrm{p}=0,01)$ між особистісною тривожністю та очікуваним відношенням від інших. Це означає, що що вищим $є$ рівень тривожності, то меншим $є$ показник очікуваного ставлення від інших, і навпаки.

- Обернений зв'язок середньої сили ( $r=-0,484$, $\mathrm{p}=0,01)$ між самоінтересом та показником особистісної тривожності. Це означає, що що більшим $є$ показник самоінтересу, то меншим $є$ рівень тривожності, й навпаки.

- Обернений зв'язок середньої сили ( $r=-0,343$, $p=0,01)$ між самовпевненістю та показником особистісною тривожністю. Отже, що меншим є рівень самовпевненості, то більшим $€$ показник особистісної тривожності, й навпаки. 
- Обернений зв'язок середньої сили ( $r=-0,517$, $p=0,01)$ між самоприйняттям та показником особистісної тривожності. Тобто чим більший показник самоприйняття, тим менший рівень тривожності, й навпаки.

- Сильний обернений зв'язок $(r=-0,646, p=0,01)$ між саморозумінням та показником особистісної тривожності. Це означає, що чим вищий рівень саморозуміння, тим менший показник особистісної тривожності, і навпаки.
Не виявлено взаємозв'язків між самопослідовністю та рівнем страху, а також між самозвинуваченням та рівнем страху і рівнем особистісної тривожності.

Для того, щоб виявити зв'язки на рівні вибірки представників пізнього юнацького віку використовуємо критерій r-Спірмена. На основі отриманих результатів було виявлено велику кількість середніх $(0,3<r<0,6)$ та декілька сильних $(r>0,6)$ зв'язків між самоставленням та рівнем страху і показником особистісної тривожності.

Таблиця 2

Взаємозв'язки самоставлення та його компонентів з загальним рівнем страху та особистісною тривожністю на рівні вибірки представників пізнього юнацького віку

\begin{tabular}{|c|c|c|}
\hline Показники самоставлення особистості & Рівень страху & Показник особистісної тривожності \\
\hline Інтегральне самоставлення & $-0,582^{* *}$ & $-0,638^{* *}$ \\
\hline Самоповага & $-0,618^{* *}$ & $-0,674^{\star *}$ \\
\hline Аутосимпатія & $-0,403^{\star *}$ & $-0,475^{\star *}$ \\
\hline Очікуване відношення від інших & $-0,372^{* *}$ & $-0,404^{* *}$ \\
\hline Самоінтерес & $-0,485^{\star *}$ & $-0,425^{\star *}$ \\
\hline Самовпевненість & $-0,583^{\star *}$ & $-0,606^{\star \star}$ \\
\hline Самоприйняття & $-0,441^{\star *}$ & $-0,485^{\star *}$ \\
\hline Самопослідовність & $-0,406^{* *}$ & $-0,481^{* *}$ \\
\hline Самозвинувачення & $-0,325^{\star}$ & $-0,413^{\star *}$ \\
\hline Саморозуміння & $-0,422^{\star *}$ & $-0,489^{* *}$ \\
\hline
\end{tabular}

Примітка: ${ }^{*} p<0,01$ - показник кореляції дуже значущий; *p<0,05 - показник кореляції значущий

Звідси бачимо, що існують такі взаємозв'язки:

- Сильний обернений зв'язок ( $r=-0,638, p=0,01)$ між інтегральним показником самоставлення та рівнем особистісної тривожності. А це означає, що чим вищий рівень самоставлення у людини, тим нижчий показник тривожності, і навпаки.

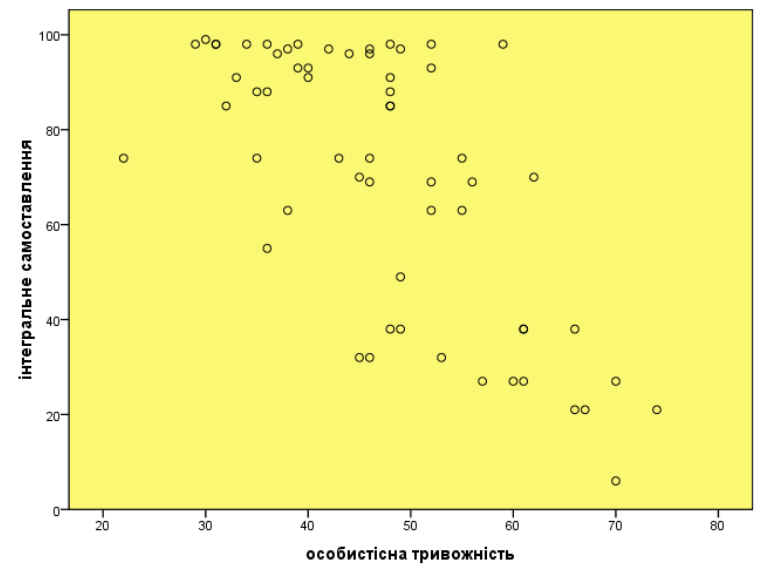

Рис. 2. Діаграма розсіювання, що показує взаємозв'язок між рівнем особистісної тривожності та інтегральним показником самоставлення на рівні вибірки пізнього юнацького віку

За діаграмою розсіювання за змінними "інтегральне самоставлення" та "особистісна тривожність" можна побачити, що зв'язок є лінійним, оберненим і сильним. На це вказує розташування точок, через які можна провести пряму. За даною діаграмою можна побачити викиди: вісь $X-60$, вісь $Y-98$; вісь $X-23$, вісь $Y-75$.

- Сильний обернений зв'язок ( $r=-0,674, p=0,01)$ між самоповагою та особистісною тривожністю. Тобто чим вищий рівень самоповаги, тим менший рівень тривожності, й навпаки.

- Обернений зв'язок середньої сили ( $r=-0,475$, $\mathrm{p}=0,01)$ між аутосимпатією та показником особистісної тривожності. Тобто чим менший рівень аутосимпатії, тим вищий рівень тривожності, та навпаки.

- Обернений зв'язок середньої сили ( $r=-0,404$, $p=0,01)$ між особистісною тривожністю та очікуваним відношенням від інших. Це означає, що чим вищий рі- вень тривожності, тим менший показний очікуваного відношення від інших, і навпаки.

- Обернений зв'язок середньої сили ( $r=-0,425$, $\mathrm{p}=0,01)$ між самоінтересом та показником особистісної тривожності. Це означає, що чим більший показник самоінтересу, тим менший рівень тривожності, й навпаки.

- Сильний обернений зв'язок $(r=-0,606, p=0,01)$ між самовпевненістю та показником особистісною тривожністю. Отже, чим менший рівень самовпевненості, тим більший показник особистісної тривожності, й навпаки.

- Обернений зв'язок середньої сили ( $r=-0,485$, $p=0,01)$ між самоприйняттям та показником особистісної тривожності. Тобто чим більший показник самоприйняття, тим менший рівень тривожності, й навпаки.

- Обернений зв'язок середньої сили ( $r=-0,481$, $p=0,01)$ між самопослідовністю та показником особистісної тривожності. Тобто чим нижчий рівень особистісної тривожності, тим більший показник самопослідовності, й навпаки.

- Обернений зв'язок середньої сили ( $r=-0,413$, $p=0,01)$ між самозвинуваченням та показником особистісної тривожності. Отже, чим нижчий рівень особистісної тривожності, тим більший показник самозвинувачення, й навпаки.

- Обернений зв'язок середньої сили ( $r=-0,489$, $\mathrm{p}=0,01$ ) між саморозумінням та показником особистісної тривожності. Це означає, що чим вищий рівень саморозуміння, тим менший показник особистісної тривожності, і навпаки.

Висновки. Представлене дослідження охоплює лише певні аспекти такого складного феномену як самоставлення. Оскільки його предметом були соціальнопсихологічні особливості самоставлення молоді юнацького віку (ранього та пізднього), то поза рамками роботи залишились інші вікові категорії, а також соціальнопсихологічні фактори, які впливають на особливості самоставлення, зокрема: матеріальне становище, повна/неповна сім'я, освіта тошо.

Розв'язання розглянутої проблеми вимагає подальших комплексних досліджень тому, що позитивне самоставлення сприяє розвитку особистості, зумовлює досягнення нею внутрішньої гармонії і психологічного здоров'я.

Надалі під час вивчення самоставлення перспективним напрямом, на нашу думку, $є$ з'ясування впливу фактору статі на особливості самоставлення, який був би корисним як у теоретичному, так і в практичному аспектах. 
Список використаних джерел

1. Бабенко О.О. Таран M.L. Теоретичний аналіз вивчення страху як психологічної проблеми у формуванні самооцінки підлітків. Науковий вісник Херсонського державного університету. Серія: Психологічні науки. $-2016,2$ (2). - С. 12-15

2. Живанова В. А. Дослідження страху як психологічного феномену в історичній ретроспективі. Вісник Національного технічного університету України Київський політехнічний інститут. Філософія. Психологія. Педагогіка. - 2010, 3. - С. 121-125.

3. Мовчан М.М. Феномен страху: його класифікація і рівні. Наукові записки [Національного університету Острозька академія]. Сер.: Філософія. - 2012, 10. - С. 197-204.

4. Мовчан М. М. Рівні страху і фобія: філософський аналіз. Філософські обрії. - 2015, 33. - С. 118-125.

5. Ольховецький С. М. Феноменологіс тривоги та страху. Проблеми сучасної психології. - 2010. - С. 9.

6. Сидоренко Ж.В., Недбалюк О.О. Проблемні аспекти самоставлення особистості в юнацькому віці. Науковий вісник Херсонського державного університету. Серія "Психологічні науки". - 2018, 1.1. - С. 163-168.

7. Ставицька С.О. Соціально-психологічні особливості реалізації потреби в саморозвитку, самооцінки життєвих цілей та самоставлення як компонентів розвитку самосвідомості в юнацькому віці. Проблеми сучасної психології. - 2014. - С. 23.

8. Царькова О.В., Радченко С.В. Теоретичні аспекти прояву психологічного феномену тривожності. Актуальні проблеми психології. - 2015, 7, Вип. 38. - С. 479-491.

9. Яворська-Вєтрова І.В. Теоретичний аналіз проблеми самоставлення: ціннісний аспект. Актуальні проблеми психології. - 2017, 13.6. - С. 198-206.
References

1. Babenko O.O., Taran M.I. Teoretychnyi analiz vyvchennia strakhu yak psykholohichnoi problemy u formuvanni samootsinky pidlitkiv. Naukovyi visnyk Khersonskoho derzhavnoho universytetu. Seriia: Psykholohichni nauky, 2016, 2 (2): S. 12-15

2. Zhyvanova V. A. Doslidzhennia strakhu yak psykholohichnoho fenomenu $v$ istorychnii retrospektyvi. Visnyk Natsionalnoho tekhnichnoho universytetu Ukrainy Kyivskyi politekhnichnyi instytut. Filosofiia universytetu Ukrainy Kyivskyi politekhnich
Psykholohiia. Pedahohika, 2010, 3: S. 121-125

3. Movchan M.M. Fenomen strakhu: yoho klasyfikatsiia i rivni. Naukovi zapysky [Natsionalnoho universytetu Ostrozka akademiia]. Ser.: Filosofiia, 2012, 10: S. 197-204.

4. Movchan M. M. Rivni ctrakhu i fobiia: filosofskyi analiz. Filosofski obrii, 2015, 33: S. 118-125.

5. Olkhovetskyi S. M. Fenomenolohis tryvohy ta strakhu. Problemy suchasnoi psykholohii, 2010, S. 9

6. Sydorenko Zh.V., Nedbaliuk O.O. Problemni aspekty samostavlennia osobystosti v yunatskomu vitsi. Naukovyi visnyk Khersonskoho derzhavnoho universytetu. Seriia "Psykholohichni nauky", 2018, 1.1: S. 163-168.

7. Stavytska S.O. Sotsialno-psykholohichni osoblyvosti realizatsii potreby $v$ samorozvytku, samootsinky zhyttievykh tsilei ta samostavlennia yak komponentiv rozvytku samosvidomosti $v$ yunatskomu vitsi. Problemy suchasnoi psykholohii, 2014, S. 23.

8. Tsarkova O.V., Radchenko S.V. Teoretychni aspekty proiavu psykholohichnoho fenomenu tryvozhnosti. Aktualni problemy psykholohii, 2015, 7, Vyp. 38: S. 479-491.

9. lavorska-Vietrova I.V. Teoretychnyi analiz problemy samostavlennia: tsinnisnyi aspekt. Aktualni problemy psykholohii, 2017, 13.6: S. 198-206.

Надійшла до редколегії 27.09.20 Рекомендована до друку 28.10.20

Larysa Terletska, PhD (Psychology), Associate Prof.,

Iryna Kukhar, Master Student

Taras Shevchenko National University of Kyiv, Kyiv, Ukraine

\section{THE RELATIONSHIPS BETWEEN FEARS, PHOBIAS, ANXIETY ON SELF-IDENTITY}

According to the aim (to identify the features of the connection of fears, phobias, anxiety with self-esteem of adolescence), an empirical study was conducted, in which the respondents were representatives of school and student youth, namely 120 people: 60 students of 10-11 grades (15-17 years) of Vyshhorod comprehensive school №2 and №3. This sample was chosen not by chance. After all, it is in adolescence is the active development and formation of all components of self-awareness, including self-esteem. According to the age periodization of M. Savchyn and L. Vasylenko, adolescence is divided into two groups: representatives of early youth (15-18 years) and late youth (18-23 years) or senior school and student age.

The presented study covers only certain aspects of such a complex phenomenon as self-assessment. As its subject was the sociopsychological features of self-attitude of adolescents and young people, other social and age categories, as well as socio-psychological factors influencing the features of self-attitude, in particular: financial status, degree of self-realization and more.

The study of this problem requires further comprehensive research, because adequate positive self-attitude is the most optimal for the formation and development of personality, determines the achievement of its inner harmony.

In our further study of self-assessment, a promising direction, in our opinion, is to clarify the features of this phenomenon in other age groups. Consideration of the influence of gender on the peculiarities of self-assessment, in this perspective, will be useful in both theoretical and practical aspects.

Keywords: fears, phobias, anxiety, emotions, self-assessment, personality.

Bulletin of Taras Shevchenko National University of Kyiv. Series "Psychology". № 1(11), pp. 63-70 (2020) УДК 159.923

DOI: https://doi.org/10.17721/BSP.2020.1(11).12

\section{ISSN 1728-3817}

(C) Taras Shevchenko National University of Kyiv,

Publishing and Polygraphic Center "Kyiv University", 2020

Світлана Чуніхіна, канд. психол. наук, ст. наук. співроб. Інституту соціальної та політичної психології НАПн України, Київ, Україна ORCID ID 0000-0002-0813-6741

\section{СУСПІЛЬНЕ СТАВЛЕННЯ ДО ОСВІТНІХ РЕФОРМ: ДОСЛІДЖЕННЯ ПРОБЛЕМИ ВІДКРИТОСТІ СУДЖЕНЬ (OPEN-MINDEDNESS)}

У статmі розглянуто проблему суперечливого ставлення громадськості до освітніх реформ у зв'язку із феноменом відкритості суджень (ореп-mindedness). На основі огляду тематичних досліджень виокремлено два великих напрями концептулізації відкритості суджень. Перший напрям вивчає відкритість суджень у контексті міжособистісної взаємодії - як відсутність упереджень по відношенню до представників груп, які інтерпретуються як "інші", готовність толерувати "інакшість" та продуктивно взаємодіяти з іншими людьми в умовах конфлікту думок та позицій. у другому напрямі відкритість суджень розглядається передусім як когнітивна налаштованість на сприймання нових ідей, толерування розмаїття думок та готовність мислити поза встановленими межами ("оut оf bох"). На вибірці з 230 респондентів досліджено зв'язок когнітивного (догматизм) та особистісного (відкритість новому досвіду) аспектів відкритості суджень із суб'єктивним ставленням до освітніх реформ. Показано, що догматизм більше пов'язаний з категоричністю суджень щодо освітніх реформ. Більш догматичні респоденти схиляються до негативних оцінок реформ, мени догматичні скоріше не мають усталених оціночних суджень. Відкритість новому досвіду визначає скоріше модальність оцінок освітніх реформ. більш "відкриті" респонденти схильні в цілому позитивніше оцінювати зміни, що відбуваються внаслідок реформ, ніж менш "відкриті", яким притаманний певний песимізм. З'ясовано, що догматизм і відкритість новому досвіду по-різному проявляють себе у ставленні до освітніх реформ серед професіоналів, зайнятих в освітній сфері, і професійно не пов'язаних $з$ освітою респондентів.

Ключові слова: відкритість суджень, догматизм, відкритість новому досвіду, суспільне ставлення, освітня реформа

В українському суспільстві сфрормувався сталий консенсус щодо необхідності реформування вітчизняної системи освіти [3]. За даними всеукраїнських репре- зентативних опитувань, що проводяться Інститутом соціальної та політичної психології НАПН України в рамках моніторингу громадської думки щодо проблем 